\title{
THE EFFECT MIND MAPPING TECHNIQUE AND VOCABULARY MASTERY ON STUDENT'S WRITING SKILL
}

\author{
Megawati, Yuliwati, Eka Rista Harimurti \\ STKIP Kusuma Negara \\ Megawati86@stkipkusumanegara.ac.id,Yuliwati@stkipkusumanegara.ac.id \\ Ekaristaharimurti@stkipkusumanegara.ac.id
}

Submitted: 2020-07-31

Accepted: 2021-05-01

\begin{abstract}
The purposes of this research is to know the effect mind mapping technique and vocabulary mastery on students'writing skill. Also how the implementation mind mapping technique on students'writing skill. Students need vocabulary mastery to arrange the sentences for getting a good paragraph and mind mapping technique is one of the technique that use to treat students for getting writing well. This research use experiments method. There were 40 students chosen at random from fourth grade semester English Education at STKIP Kusuma Negara Jakarta.Collecting data use test writing skill. Research of instrument has tested and tried by the validity and reliability test used the SPSS (Statistic Program Social Science). Data analyzed by using kolmogorv Smirov, know data was normality.The text analysis is to test the data homogeneity by using Levenu's test, to see if the population was derived from homogeneous population. The result of this research concluded that 1) Using Mind Mapping Technique has significant effect on student's writing skill. Result F for mind mapping (A) $\mathrm{Fo}=290.285$ and sig. $=0.000<0.05$, then the conclusion is that there is significant effect between mind mapping technique (X1) on student's writing skills. 2). Vocabulary mastery gave the significant effect to the student's writing skill. Result research F for vocabulary mastery (B) Fo=91.401 and sig. $=0.000<0.05$. It has shown that there is significant effect vocabulary mastery $(\mathrm{X} 2)$ on student's writing skills. 3) There is significant effect interaction between mind mapping and vocabulary mastery on student's writing skill. Result of this research F from mind mapping (A) and vocabulary (B) $\mathrm{Fo}=5.274$ and sig. $=0.028<0.05$. Using mind mapping technique in learning give effect in students'writing skill. Students who have rich vocabulary mastery can get good writing English.
\end{abstract}

Keywords: Podcasts, Promote, Speaking, Online Learning

\section{INTRODUCTION}

Nearly all the people of many different countries around the world use language to communicate. In communication, people need language. Without language, people can get difficult to communicate.Language as communication. There are two communication. It is verbal communication and nonverbal communication. Language become verbal communication. We use language to communicate with other people. In communication we can speak or write. Writing is the activity write the idea or imagination, share information by letter or type using mobile phone, computer, etc. Letter form sign or symbol and other people understand what someone write. For getting writing English well, It has supported by structure and grammar, punctuation, vocabularies.

All skills have to be taught integrated to achieve English skills goals. Vocabulary is one of the important elements shared by all four skills. Mastering the vocabulary is a basic part to learn English skills. Students have to rich vocabulary in order that it can support them in writing skill. Students unusual open dictionary to find the meaning of the words if they get the difficult words. 
Students just asked with their friends and lecturer word by word, It makes them have limitation meaning in vocabulary building.

For getting rich vocabulary, lecturer asks students to remember words an phrase also arrange into a good sentences. Lecturer applied mind mapping technique in learning. It's one of the technique in which support them to get writing well. Before students write paragraph, lecturer ask them to collect words and phrase which has relation with the theme or main idea. Theme or main idea has been given by the lecturer and then students draw mapping concept the theme.After that students add symbols such as ruler and narrow as branch of the main idea. Then students arrange sentences by using words, phrase which collected in mind mapping.

This technique supports students in writing skill. Students can make sentences and written essay with the vocabulary in thought thinking process.According to Lankshear (2000:163) stated that in writing people use tools or media to write an idea by using pencil, typewriter, or other technology in order that other people can get the new information. Pincas (1998: 56) stated that the way communication can be written something. The write who writer can read by the reader. Written is expression the writer about the idea. It can be how the writers'feel. It purpose are giving expression the writer's self, giving information to the reader about something and persuade the reader to doing the writer want.It means that in writing, we can communicate with other people in the world. People can express what they felt in their life by sign in written in text, tell something happen, tell about his/her condition to the reader. Reader can know information in which the writer made.

Barli Bram (1995: 23) stated that produce knowledge, information should be arrange on the paper.Process organize the ideas, production in written massage in paper so someone who read the message can understand what is the content. Morris, Rupperd (1999:22) stated that an activity write a symbols, feeling expression thus other people know and understand what the writer means. It means that writing skills is the express an idea in paper, write feelings and thought by the writer. According to Simanjuntak (2020:56) for getting writing skill, the writer should be be master vocabulary, spelling, grammar, punctuation, and organizing ideas into sentence and paragraphs. It means that students should be taught by the lecturer in order that students can understand the requirement criteria in writing. In writing lecturer asks the students not only grammatical, sentence structure but also content the material writing is needed . Before the students write what they thought, they must have knowledge the element of writing.

Andrew Wright (2007:58) stated that send message something to another. In class, someone make text message by reading text then lecturer response for correct it. In classroom, students write what they listen from the lecturer and then students give response to lecturer. It happen feed back between teacher and students. According to Ilona leki (1998:5) writing is communicating. Good writing helps your reader understand your ideas as clearly as possible. It means that writing is communicate between writer to a reader, writer gives an idea with a written text and the reader can 
understand the information from the writer. The writing skill are complex activity, writing like communication between lecturer to the students. Lecturer gives information an idea, thought, news and then send it to the other people. Students catch all information and understand what the writer means also believe it. Teaching is a profession that is conducted by using combination of art, science, and skill. According to Richards (2002: 255) stated that teaching vocabulary is the primary important in learning foreign country but now teaching vocabulary always changed. Vocabulary is basic in teaching writing. According to Penny (1991:60) Vocabulary describes words which use to teaching send language. Furthermore several words combine then become phrase, idiom. That can't separated each other. According to Patricia Richard-Amato (2005:446) Vocabulary can be best be introduced using real object, pictures, and other visual devices. It means that vocabulary is the way introducing by teacher in a real object, pictures, and something the around environment to the students. Students must memorize vocabularies for requiring in writing. According to Raja T. Nasr (1972:57) Vocabulary building means knowing means the meanings of words; the ability to understand words as they are used in situations. It means that vocabulary building must be known by the students. Students can make a good sentence if they have a lot of vocabularies. They can say what they thought in written. Then people can know information from the written in which they write. According Andrew Wright (2006:94) teaching vocabulary is giving word then translate into Bahasa Indonesian. It conclude that vocabulary means real object, picture or other device in teaching. They can write what they felt, what they know, opinion, imagination and suggestion to something in written text. If student have limited vocabularies, they get difficult to write.

\section{Definition Mind Mapping}

Using mind mapping technique can create new something because it can stimulus for thinking through association branch in which we have written. Each of words, pictures and illustration in which you made, it help you to think logical, synergic and working together. It's need you to develop them. According to Buzan (2002:6)mind mapping means make concept, an idea from the mind or brain on a paper then make branch from the main idea which support the idea. According to Parikh (2016:149) stated that Mind Mapping is the way for send information effectively and efficiently, mapping an idea with creative picture and symbols. It use to activate right brain, through pictures, shapes which make by lecturer. It easiest students to remember new knowledge and material of the lesson.

According to Priyasudiarja (2014:45) Mind map is technique teaching in which improving visual learning style. Lecturer use visual learning style in classroom activity. Teacher draw circle and the write the main idea, After that teacher makes branch of the main idea. Students mention clue or words in which connection with the main idea. Then students asked to make sentence and paragraph about descriptive text.

\section{Step-step in Mind Mapping Technique}

Megawati, Yuliwati, Harimurti. The Effect.. 
According to Tony Buzan (2005:9), they were some procedure to make mind mapping : firstly lecturer decided to put the main idea or theme, for example College, Then Lecturer draw a shape ovale or round. The main idea should be write in the center of the shape. After that lecturer draw line as the branches of the shapes. Lecturer use various color in order that supporting detail can clearly to seeing. Students who see concept can understand and easy to remember. Kind of color can activate right brain the whole.

\section{Advantages use mind mapping}

Describes main idea, topic, motion, or theme clearly because it uses words, phrase or sentences which relation with the idea. Also it easiest remembering by memory because it applies various color in line, shape, curve, picture. Furthermore it can balance right brain and left brain. Use right brain to imagination an idea. Then use left brain for improve in writing a text.

\section{Element for giving score in writing skill based on Heaton (1998: 146)}

Firstly, Content should be relevant with the topic. It's develop the topic. The arranged should be suitable with the logical. Secondly, The writer have to organize the topic, determine the main idea and what are supporting details. Thirdly, The writer should use dictation, words in sequencing sentences. Fourthly, The writer make sentences effectively when construction rules in structure and grammar. Fifthly, Pay attention in mechanics such as use capitalization, punctuation, paragraphing, errors in spelling.

\section{RESEARCH OF THE METHOD}

Researcher use experimental method. It uses ANOVA two ways. Experiment was given to two classes in which each of class given different treatment. First classes taught mind mapping technique and the second class taught conventional learning. Each of classes divide two category, high vocabulary mastery (B1) and low vocabulary mastery (B2)

Table 1.

\begin{tabular}{|l|c|c|}
\hline $\begin{array}{l}\text { Technique(A) } \\
\text { Vocabulary (B) }\end{array}$ & Mind Mapping (A1) & Conventional Learning (A2) \\
\hline High vocabulary mastery (B1) & A1B1 & A2B1 \\
\hline Low Vocabulary mastery (B2) & A1B2 & A2B2 \\
\hline$\Sigma$ Total & $\Sigma$ A & $\Sigma$ B \\
\hline
\end{tabular}

A1 : Mind Mapping technique

A2 : Conventional Learning

B1 : Students have high vocabulary

B2 : Students have low vocabulary

A1B1 :Result students' writing skill which use mind mapping and high vocabulary mastery 
A2B1 :Result students' writing skill which use mind mapping and low vocabulary mastery

A1B2 :Result students' writing skill which use mind mapping and low vocabulary mastery

A2B2 :Result students' writing skill which use conventional learning and low vocabulary mastery

There are two independent variable and one dependent variable. Two independent variables consist of Mind Mapping (X1) and Variable Vocabulary Mastery (X2). Moreover The dependent variable consists Student's Writing Skill (Y). Target of population is students English education program STKIP Kusuma Negara. 20 students as the sample in experiment class and 20 students as the sample in control class. The data was gotten from instrument that consist of: (1) Instrument vocabulary mastery, (2) Instrument questionnaire mind mapping technique, (3) Instrument test the student's Writing skill

\begin{tabular}{|l|r|r|r|r|}
\hline & $\begin{array}{c}\text { Scale Mean if } \\
\text { Item Deleted }\end{array}$ & $\begin{array}{c}\text { Scale } \\
\text { Variance if } \\
\text { Item Deleted }\end{array}$ & $\begin{array}{c}\text { Corrected } \\
\text { Item-Total } \\
\text { Correlation }\end{array}$ & $\begin{array}{c}\text { Cronbach's } \\
\text { Alpha if Item } \\
\text { Deleted }\end{array}$ \\
\hline B1 & 11.17 & 24.764 & .492 & .856 \\
B2 & 11.17 & 24.282 & .597 & .852 \\
B3 & 11.33 & 25.609 & .300 & .863 \\
B4 & 11.20 & 24.924 & .449 & .858 \\
B5 & 11.23 & 24.392 & .555 & .854 \\
B6 & 11.10 & 25.059 & .457 & .857 \\
B7 & 11.20 & 25.821 & .264 & .864 \\
B8 & 11.17 & 24.282 & .597 & .852 \\
B9 & 11.20 & 25.200 & .392 & .860 \\
B10 & 11.20 & 25.062 & .420 & .859 \\
B11 & 11.17 & 24.144 & .628 & .851 \\
B12 & 11.17 & 25.592 & .318 & .862 \\
B13 & 11.33 & 24.851 & .454 & .857 \\
B14 & 11.17 & 25.385 & .361 & .861 \\
B15 & 11.17 & 25.109 & .419 & .859 \\
B16 & 11.20 & 24.924 & .449 & .858 \\
B17 & 11.27 & 24.754 & .474 & .857 \\
B18 & 11.27 & 24.823 & .460 & .857 \\
B19 & 11.17 & 24.420 & .567 & .853 \\
B20 & 11.33 & 24.851 & .454 & .857 \\
\hline
\end{tabular}

Reliability Statistics

\begin{tabular}{|c|r|}
\hline $\begin{array}{c}\text { Cronbach's } \\
\text { Alpha }\end{array}$ & N of Items \\
\hline .864 & 20 \\
\hline
\end{tabular}

Reliability for variable vocabulary mastery (X2), if alpha $>0.60$, it said that instrument are reliable. From this table below. It can b seen Alpha Cronbach $0.864>0.60$. It means that instrument for vocabulary mastery is reliable.

\section{DISCUSSION}

This research is experiment in which have two factors. These are mind mapping technique (X1/A) and vocabulary mastery (X2/B). Each of factor is level. Mind mapping factor (A) has two level, first it using mind mapping technique (A1) and second it using conventional learning (A2). Meanwhile variable X2/B has two level. First students who high vocabulary mastery (B1) and second students who low vocabulary mastery. There are conclusion descriptive text in which we have seen in table.

\begin{tabular}{|l|l|l|l|}
\hline $\begin{array}{l}\text { Vocabulary } \\
\text { Mastery (B) }\end{array}$ & Mind Mapping (A1) & Conventional (A2) & Total \\
\hline High (B1) & $\mathbf{n}=\mathbf{1 0}$ & $\mathbf{n}=\mathbf{1 0}$ & $\mathbf{n}=\mathbf{2 0}$ \\
& $\mathbf{x}=\mathbf{9 0 . 7 0}$ & $\mathbf{x}=\mathbf{8 3 . 9 0}$ & $\mathbf{8 7 . 3 0}$ \\
\hline
\end{tabular}




\begin{tabular}{|l|l|l|l|}
\hline & $\mathbf{s}=\mathbf{3 . 0 2 0}$ & $\mathbf{s}=\mathbf{2 . 7 2 6}$ & $\mathbf{s}=4.473$ \\
\hline Low (B2) & & & \\
& $\mathbf{n}=\mathbf{1 0}$ & $\mathbf{n}=\mathbf{1 0}$ & $\mathbf{n}=\mathbf{2 0}$ \\
& $\mathbf{x}=\mathbf{7 6 . 9 0}$ & $\mathbf{x}=\mathbf{6 5 . 8 0}$ & $\mathbf{x}=71.35$ \\
& $\mathbf{s}=\mathbf{3 . 1 0 7}$ & $\mathbf{s}=\mathbf{2 . 9 7 4}$ & $\mathbf{s}=\mathbf{6 . 4 1 8}$ \\
\hline Jumlah & $\mathbf{n}=\mathbf{2 0}$ & $\mathbf{n}=\mathbf{2 0}$ & $\mathbf{n}=\mathbf{4 0}$ \\
& $\mathbf{x}=\mathbf{8 3 . 8 0}$ & $\mathbf{x}=\mathbf{7 4 . 8 5}$ & $\mathbf{x}=\mathbf{7 9 . 3 3}$ \\
& $\mathbf{s}=\mathbf{7 . 6 8 2}$ & $\mathbf{s}=\mathbf{9 . 6 9 1}$ & $\mathbf{s}=\mathbf{9 . 7 4 9}$ \\
\hline
\end{tabular}

A1B1 = Mind mapping technique and high vocabulary

A1B2 = Mind mapping technique and low vocabulary

$\mathrm{A} 2 \mathrm{~B} 1=$ Conventional learning and high vocabulary

A2B2 = Conventional learning and low vocabulary

From the table descriptive above researcher give conclusion that mean result writing skill in which use mind mapping technique more high than result writing skill in which use conventional learning. It uses mind mapping technique 83.80 and conventional learning 74.85

Mind mapping technique proved to increase student's writing skills

While the average students learning has high vocabulary, result student's writing skill bigger than the average students has low vocabulary. The average students has high vocabulary is 87.30 and Average students has low vocabulary is 71.35 It means that $74.20>64.90$

\section{Dependent Variable : Student's writing skill}

\begin{tabular}{|c|l|c|c|c|}
\hline Learning Technique & Vocabulary Mastery & Mean & Std. Deviation & N \\
\hline \multirow{3}{*}{$\begin{array}{c}\text { Mind Mapping } \\
\text { Technique }\end{array}$} & High vocabulary mastery & $\mathbf{9 0 . 7 0}$ & $\mathbf{3 . 0 2 0}$ & $\mathbf{1 0}$ \\
\cline { 2 - 5 } & Low vocabulary mastery & $\mathbf{8 3 . 9 0}$ & $\mathbf{2 . 7 2 6}$ & $\mathbf{1 0}$ \\
\cline { 2 - 5 } & Total & $\mathbf{8 7 . 3 0}$ & $\mathbf{4 . 4 7 3}$ & $\mathbf{2 0}$ \\
\hline \multirow{3}{*}{ Conventional } & High vocabulary mastery & $\mathbf{7 6 . 9 0}$ & $\mathbf{3 . 1 0 7}$ & $\mathbf{1 0}$ \\
\cline { 2 - 5 } & Low vocabulary mastery & $\mathbf{6 5 . 8 0}$ & $\mathbf{2 . 9 7 4}$ & $\mathbf{1 0}$ \\
\cline { 2 - 5 } & Total & $\mathbf{7 1 . 3 5}$ & $\mathbf{6 . 4 1 8}$ & $\mathbf{2 0}$ \\
\hline \multirow{3}{*}{ Total } & High vocabulary mastery & $\mathbf{8 3 . 8 0}$ & $\mathbf{7 . 6 8 2}$ & $\mathbf{2 0}$ \\
\cline { 2 - 5 } & Low vocabulary mastery & $\mathbf{7 4 . 8 5}$ & $\mathbf{9 . 6 9 1}$ & $\mathbf{2 0}$ \\
\cline { 2 - 5 } & Total & $\mathbf{7 9 . 3 3}$ & $\mathbf{9 . 7 4 9}$ & $\mathbf{4 0}$ \\
\hline
\end{tabular}

\section{Normality Test}

Normality test in dependent variable is needed. In this research will continuous with analysis parametric. It is analysis of variance (ANOVA) or it uses analysis general (GLM).

For determine this variable normal or abnormal. Researcher conducted with Kolmogorof -smirnof with SPSS 22.00. In this case being tested is hypothesis null (Ho). To show that Ho is rejected, so It conducted with compare p-value with significance level 0.05 .

According to criteria: If sig. $>0.05$ : so data distribute normal

If sig. $<0.05$ : not normally distribute

\section{Variable Student's writing skill}


One-Sample Kolmogorov-Smirnov Test

\begin{tabular}{|ll|r|}
\hline & & Writing Skill \\
\hline Normal Parameters & & 40 \\
& & 79.33 \\
Most Extreme Differences & Mean & 9.749 \\
& Std. Deviation & .103 \\
& Absolute & .081 \\
& Positive & -.103 \\
Kolmogorov-Smirnov Z & Negative & .649 \\
Asymp. Sig. (2-tailed) & & .794 \\
\hline \multicolumn{2}{|c|}{ a. Test distribution is Normal. }
\end{tabular}

b. Calculated from data.

From the above table shown that result student's writing skill Senior High School

It has a value of statistical test Kolmogorof Smirnov $Z=0.649$ and sig. $=0.749$

It means $\mathrm{Ho}=$ receive. Data result student's writing skill (descriptive text) following normally distribution.

\section{Homogenity Test}

Homogenity Test purposes to know what variant come from population in which homogeneity.

Homogenity Test data student's writing skill conducted use Levene Test with sig. 0.05

In homogeneity Test. There are :

Ho : Data from homogeneity population

H1 : Data from in homogenous population

With criteria:

If sig. >0.05; so Ho is receive,

From the above data with SPSS 22.00. It gets sig. $=0.907>0.05$. Therefore $\mathrm{Ho}=$ receive and $\mathrm{H} 1=$ rejected . Data come from population homogeneity. From result hypothesis and homogeneity test. It can concludes fulfillment requirement, so It can continue to hypothesis.

\section{Homogeneity Test Variable Y}

Student's writing skill

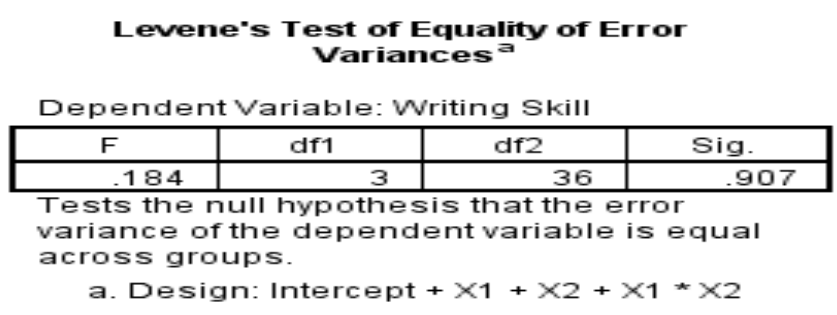

\section{Hypothesis Test}

After researcher conducted normality and homogeneity. After that the result shown sample of this research population is normal distribution, also variant sample is homogeny, so hypothesis test uses ANOVA can be done. 
Result student's writing skill continuous with T-test for to know significant different between each of group. Moreover T-test purposes to know which one group have result high student's writing skill if viewed from vocabulary mastery. As for data analysis by using Anova, It can see from the table below.

Tests of Between-Subjects Effects

Dependent Variable: Writing Skill
\begin{tabular}{|l|r|r|r|r|r|}
\hline Source & $\begin{array}{c}\text { Type III Sum } \\
\text { of Squares }\end{array}$ & df & Mean Square & \multicolumn{1}{c|}{ F } & Sig. \\
\hline Corrected Model & $3391.275^{2}$ & 3 & 1130.425 & 128.987 & .000 \\
Intercept & 251698.225 & 1 & 251698.225 & 28719.924 & .000 \\
$\times 1$ & 2544.025 & 1 & 2544.025 & 290.285 & .000 \\
$\times 2$ & 801.025 & 1 & 801.025 & 91.401 & .000 \\
$\times 1 \star \times 2$ & 46.225 & 1 & 46.225 & 5.274 & .028 \\
Error & 315.500 & 36 & 8.764 & & \\
Total & 255405.000 & 40 & & & \\
Corrected Total & 3706.775 & 39 & & & \\
\hline
\end{tabular}
a. R Squared $=.915$ (Adjusted R Squared $=.908$ )

According the data above, researcher can conclude :

\section{Hypothesis Test 1 :}

There is effect mind mapping towards student's writing skill. Hypothesis test uses to know coefficient significant.From Hypothesis Test using SPSS 22.00 above. It gets F for mind mapping (X1) Fo $=290,285$ and sig. $=0.000<0.05$. There is significant effect mind mapping on student's writing skill. Average result student's writing skill in which uses mind mapping more high than students use conventional learning.

2. Hypothesis 2 :

There is effect vocabulary mastery on student's writing skill. Hypothesis test to know coefficient significant.From hypothesis test using SPSS 22.00 above. It gets for vocabulary mastery (X2) Fo $=91.401$ and sig. $=0.000<0.05$. There is significant effect vocabulary mastery on student'swriting skill. Average result student's writing skill with vocabulary mastery higher than students has high vocabulary mastery.

3. Hypothesis Test 3 :

There is relation effect between mind mapping and vocabulary mastery on students' writing skill. Hypothesis test to know coefficient significant.From Hypotesis Test using SPSS 22.00 above. It gets for Mind Mapping (A) and vocabulary mastery (B) $F o=5.274$ and sig. $0.028<0.05$. It can be shown that there is significant relation between mind mapping and vocabulary mastery on student's writing skill. 


\section{CONCLUSION}

From result of the research above, it can be concluded that there is significant effect mind mapping technique on students'writing skill, and there is significant effect vocabulary mastery on students'writing skill also there is significant relation between mind mapping and vocabulary mastery on students'writing skill. Mind mapping is one of the alternative technique in which appropriate for lecturer to teach students'writing skill. This technique is very useful in achieving students writing skill. Students can increase their writing skill. Written English is different with the pronounce in English. in writing skill, students need understanding structure, grammar, dictation, and other rules when they are writing. They will get English in writing well. Through this technique, students can focus in main idea of the theme, use picture, symbols also use kind of colour. The function of colour is emphasize and remembering students for supporting in words or phrase which relation with the main idea. Students can improve their language and imagination when they arrange sentences into a good paragraph. Furthermore students who have vocabulary mastery, they can write a good paragraph become a text.

\section{REFERENCES}

Amato, Patricia A, Richard. (2005). Academic Success For English Language Learners Strategies For K-12 mainstream teachers. USA: longman

Buzan, Tony. (2005). The Ultimate book of Mind Maps. Harper Collin Publisher : London

Buzan, Tony. (2002). How to Mind Map: The Ultimate Thingking Tool That Will Change YOUR Life. London: Thorson.

Barly, Bram. (1995). Write well: Improving Writing Skills. Yogyakarta: Kanisius

Hornby, A.S., (1985). Oxford Advanced Learner's Dictionary of Current English .London:Oxford University Press

Heaton, J.B. (1988). Writing English Language Test. United States of America: Longman Group Lankshear and Snyder.(2000). Second Language Writing. Cambridge Language Education. P163

Leki, ilona. (1998). Academic writing exploring process and strategies. Cambridge University Press. Cambridge

Morris, Rupperd, Smith Hurried.(1999).Business writing orien business book: Great Britain

Nunan, David.(1989).Desugning Tasks for the Communicative Classroom. Cambridge, Cambridge University Press

Parikh, Nikhilkumar D. (2016). Effectiveness of Teaching through Mind Mapping Technique. The International Journal of Indian Psychology. ISSN 2348-5396 (e) | ISSN: 2349-3429 (p). 
Volume 3, Issue 3, No.3, DIP: 18.01.054/20160303. ISBN: 978-1-365-03419-0. http://www.ijip.in | April - June, 2016. P.(148-156)

Priyasudiarja, Yusup.(2014). Pintar Bahasa Inggris dengan Mind Map, 2014. Kawah media, Jakarta selatan

Pincas. (1998). Teaching English Writing: Essential Language Teaching Series. London: The Macmilan Publisher

Penny Ur,(1991), A course in Language Teaching Practice and Theory. Cambridge: Cambridge University Press

Riswanto and Pebri Prandika Putra. (2012). The Use of Mind Mapping Strategy in the Teaching of Writing at SMAN 3 Bengkulu, Indonesia. International Journal of Humanities and Social Science: USA. Vol, 2. No. 21; Novemberv2012. Taken from www. ijhssnet.com

CR Simanjuntak, dkk. (2020). The effect of Mind Mapping Technique in students'Writing Skills of Narrative Text at Second Grade of SMA Swasta GKPI Padang Bulan Medan. Borneo Journal of Education. Vo, 2. No. 2; tahun 2020 ISSN: 2654-329X

Nasr, Raja T. (1972). Teaching and learning English. Selected and Simplified Readings. Beirutlebanon: longman Group

Wright, Andrew.(2007). Games for Language Learning. Cambridge: Cambridge University Press 